\title{
Craton vs. rift uppermost mantle contributions to magnetic anomalies in the United States interior
}

\author{
Friedman, S.A. ${ }^{1}$, Feinberg, J.M. ${ }^{2}$, Ferré, E.C. ${ }^{1}$, Demory, F. ${ }^{3}$, Martín-Hernández, F.4,5, Conder, \\ J.A. ${ }^{1}$, and Rochette, $\mathrm{P}^{3}$ \\ ${ }^{1}$ Department of Geology, Southern Illinois University, Carbondale IL 62901-4324, U.S.A. \\ ${ }^{2}$ Institute for Rock Magnetism, University of Minnesota, Minneapolis, MN 55455-0219, U.S.A. \\ ${ }^{3}$ CEREGE, CNRS, BP 80, Aix-Marseille University, 13545 Aix-en-Provence, France \\ ${ }^{4}$ Departamento de Física de la Tierra I: Geofísica y Meteorología, Facultad de Física, Universidad Complutense de \\ Madrid, 28040 Madrid, Spain \\ ${ }^{5}$ Instituto de Geociencias IGEO (UCM-CSIC), Fac. CC. Físicas, Madrid, Spain
}

\begin{abstract}
The interpretation of satellite magnetic information (Magsat, Oersted, CHAMP, Swarm) requires understanding the mineralogy of crustal and mantle sources. Also, spectral analysis of magnetic data over forearcs and cratons calls for upper mantle contribution. The prospect of such a contribution contradicts the view that the mantle is too hot and too weakly magnetic to influence magnetic anomalies.

Here we examine the rock magnetic properties of fresh mantle xenoliths from four settings across the United States: phlogopite-spinel dunites from the Bearpaw Mountains, Montana, and lherzolites/harzburgites from San Carlos, Arizona; Kilbourne Hole, New Mexico; and Knippa, Texas. Paleomagnetic results show single-component natural remanent magnetizations (NRM), which, combined with optical and secondary electron microscopy support the lack of post-
\end{abstract}


eruption alteration and absence of host-rock contamination. The NRM carriers include magnetite at Bearpaw Mountain and San Carlos, and pyrrhotite at Kilbourne Hole and Knippa. These four areas show continental crust of distinct thicknesses and various geotherms. The potential mantle contribution to magnetic anomalies is forward modeled using crustal thickness, current geotherm and average magnetic properties of xenoliths. The San Carlos and Kilbourne Hole mantle, situated near the Rio Grande Rift is too hot and too weakly magnetic to contribute to anomalies. The sulfide-dominated assemblage at Knippa does not support magnetization at mantle depths. In contrast, the Bearpaw Mountains combine a relatively cold geotherm (craton) and abundance of magnetite formed at mantle depth. This cratonic mantle, metasomatised by fluids from the Farallon plate, may contribute to long wavelength magnetic anomalies.

\section{Introduction}

Since the launch of Magsat in 1979, the uppermost mantle has been considered too hot and too weakly magnetic to contribute to long wavelength magnetic anomalies (LWMA) (Wasilewski et al. 1979; Wasilewski and Mayhew, 1992). Yet, spectral analysis of satellitederived magnetic data over cratonic areas requires contributions from the uppermost mantle (e.g.; Hemant and Maus, 2005a; Thébault et al., 2010; Purucker and Clark, 2011). Further, recent results on the magnetic properties of cratonic mantle xenoliths document significantly larger induced and remanent magnetizations than previously suggested (Friedman, 2011, unpublished; Ferré et al., 2013). Also, the Swarm magnetic satellite constellation, successfully launched November 22, 2013, promises new data of unprecedented quality with which to explore lithospheric sources of magnetic anomalies in the crust and upper mantle. Recent results also suggest significant variations of the mantle magnetic properties as a function of tectonic setting 
(Friedman, 2011, unpublished; Ferré et al., 2013). While the respective contributions of melt extraction, oxygen fugacity and metasomatism in these variations remain unclear, we propose that the uppermost mantle of the United States interior may not be uniformly non-magnetic. With this in mind, the continent-wide EarthScope geophysical program provides new opportunities to identify areas of low geothermal gradient where the shallow uppermost mantle could be magnetic (Figure 1).

\section{Previous magnetic investigations}

Early magnetic studies of mantle xenoliths, motivated by the launch of the Magsat satellite mission in 1979, were based on 400 xenoliths from various localities including Hawai'i, the Rio Grande Rift, South Africa and Antarctica (Wasilewski et al., 1979; Wasilewski, 1987; Wasilewski and Mayhew, 1992; Warner and Wasilewski, 1995). Magnetic remanence data are available for only 131 of these xenoliths. This collection of xenoliths includes rock types such as garnet peridotites and eclogites, formed at high-temperature, which clearly would not be able to carry a magnetic remanence at mantle depths. Such material, does not inform us about the in-situ magnetic remanence of the mantle. Other xenoliths $(\approx 30 \%)$ correspond to volumetrically minor components of the lithospheric mantle such as wehrlites. Among the remaining samples, thirty percent display macroscopically visible alteration (e.g., \#110597; Wasilewski et al., 1979) and approximately twenty percent show contamination by host basalt (e.g., \#ANT50; Warner and Wasilewski, 1995). Some of the specimens show microstructural evidence of incipient partial melting at olivine-chromite grain boundaries (Warner and Wasilewski, 1995), suggesting reactions during ascent. Of the 26 remaining unaltered and uncontaminated samples, saturation magnetization $\left(\mathrm{M}_{\mathrm{s}}\right)$ was reported for 22 samples, while magnetic susceptibility $(\chi)$ was reported 
for 11 samples. This small dataset shows a large variability $\left(\mathrm{M}_{\mathrm{s}}\right.$ ranges over 3 orders of magnitude, and $\chi \square \square \square \square \square \square$ by a factor of $4 \tilde{0}$ Specimens from the Southwest United States are overrepresented in this collection of 26 xenoliths $(\sim 40 \%)$. A more recent study on uncontaminated Spl-lherzolites and pyroxenites from the Rio Grande Rift volcanics in New Mexico (Callahan, 2009, unpublished) shows that lherzolites host multidomain (MD) magnetite whereas the pyroxenites contain single-domain stoichiometric magnetite, both interpreted as having formed in the mantle and characterized by a Curie temperature $\mathrm{T}_{\mathrm{c}}$ of $580^{\circ} \mathrm{C} . \chi$ ranges from $\approx 10^{-4}$ to $10^{-5}$ [SI]. Microstructural evidence further suggests that oxidation by carbonatitic melt or fluid occurred at mantle depth and led to formation of hematite $\left(\mathrm{T}_{\mathrm{c}}=680^{\circ} \mathrm{C}\right)$, prior to transport in the host basalt. TEM analyses also revealed micro-inclusions of amorphous silica and magnetite within olivine indicative of formation at or close to the fayalite-magnetite-quartz (FMQ) buffer, while the presence of hematite in a few samples requires $f \mathrm{O}_{2}$ to be close to the hematite-magnetite (HM) buffer.

\section{Petrography and petrology}

The mantle xenoliths of this study originate from four previously studied localities of the United States interior (Figure 1): 1. The Bearpaw Mountains Eocene volcanics in Montana (Facer et al., 2009); 2. The Pleistocene San Carlos Mesa volcanics in Arizona (Frey and Prinz, 1978); 3. The 80-140 ka Kilbourne Hole maar in New Mexico (Bussod and Williams, 1991); and 4. The Late Cretaceous Knippa basanite plug in Texas (Raye et al., 2011). Our specimens, collected in the field during the Summer 2010, are fresh and free of host-rock contamination. Their petrographic characteristics, observed by both optical and electron microscopy (Figure 2), match those described in previous studies on the same localities. Each locality yielded at least ten 
hand specimens. Specimens for magnetic studies were cut from the core of the freshest xenoliths to produce ten cubes per locality.

The Bearpaw Mountains xenoliths (Figures 2A, 3A) have previously been extensively described in Facer et al. (2009). They consist of small (up to $10 \mathrm{~cm}$ in diameter) phlogopitespinel dunite xenoliths with thin, brownish reaction rims $(<3 \mathrm{~mm})$. Mineral assemblages generally consist of olivine (>80\%), enstatite (10-15\%), phlogopite (5-10\%), chrome spinel (1$2 \%)$, brown amphibole (1-2\%) and antigorite (1-2\%). Microstructures are overall granoblastic with rounded olivine and enstatite grains typically around 0.5 to $2 \mathrm{~mm}$ in diameter. Our specimens share the same petrographic features described by Facer et al. (2009) as Category 1 and Category 2 xenoliths. In Category 1 xenoliths, olivine-olivine grain contacts display thin films of antigorite hosting small alignments of magnetite grains. In Category 2 xenoliths, magnetite also forms on the rim of chromite and in-between diopside grains (Figure 3A).

The San Carlos xenoliths (Figure 2B) have been petrographically described in detail by Frey and Prinz (1978) and by Irving (1980). Our specimens correspond to the most abundant Group I Cr-rich diopside dunite specimens of Frey and Prinz (1978). Large xenoliths ( $>0.3 \mathrm{~m})$ commonly are cut by diffuse, $\approx 25 \mathrm{~mm}$-thick, Cr-rich diopside veins. These xenoliths have been excluded from this study due to their heterogeneous nature. The basanite melt carrying the xenoliths originates from a small degree of partial melting of a garnet peridotite and is not related to the dunite. These dunites are generally not contaminated by the host basanite. Magnetite inclusions up to $5 \mu \mathrm{m}$ in length occur in some of the olivine porphyroclasts.

The Kilbourne Hole xenoliths (Figures 2C, 3B) have been described by Dromgoole and Pasteris (1987) and by Bussod and Williams (1991). Our specimens consist of Cr-diopside spinel lherzolites and spinel harzburgites and exhibit protogranular microstructures. Volumetrically 
minor lithological rock types, such as pyroxenites, were not included in this study. Our samples consistently display coarse grain sizes $(2-4 \mathrm{~mm})$. Because macroscopic reaction rinds extend up to $25 \mathrm{~mm}$ in width, only the core of the largest xenoliths were used for sample preparation. Metasomatic phases, such as antigorite, amphibole or phlogopite, were not observed in these specimens. Finally, spongy rims around clinopyroxenes suggest reactions during ascent. Monosulfide solid solution (pyrrhotite) and other $\mathrm{Cu}-\mathrm{Ni}-\mathrm{Fe}$ sulfides such as chalcopyrite (Figure 3B) are relatively common in these peridotites (Dromgoole and Pasteris, 1987). Whereas these authors describe secondary magnetite isolated in silicate in clinopyroxenites (KH77-20), we did not find magnetite in these lherzolites.

The Knippa xenoliths (Figure 2D) have been recently described by Frey and Prinz (1978), Young and Lee (2009), and Raye et al. (2011). Our xenoliths are coarse grained, equigranular, and consist of fresh spinel lherzolite hosted in aphyric basanite. Xenoliths that showed lizardite veins or a macroscopic foliation marked by elongated spinel and orthopyroxene, were not included in the magnetic study. Grain boundaries are straight and exhibit well-developed triple junctions indicative of equilibration at high temperature. All grains are free of chemical zoning, however spongy rims around clinopyroxenes occur occasionally. A few olivine porphyroclasts display a slight kink banding. Magnetite has not been observed microscopically in these xenoliths but small grains of pyrrhotite $(1-3 \mu \mathrm{m})$ associated with apatite are present in lizardite veins.

\section{Analytical methods}

Magnetic measurements - Non-oriented $10 \mathrm{~mm}$ cubes were cut from the center of the largest available xenoliths using non-magnetic, diamond-impregnated blades. Specimens with multiple 
natural remanent magnetization (NRM) components were deemed altered (Friedman, 2011, unpublished; Ferré et al., 2013) and excluded from this study. Two adjoining cubes were prepared from each xenolith, and all specimens are free of host-rock contamination (such as basaltic glass). Low-field, room temperature, magnetic susceptibility was determined using a Kappabridge KLY-4S susceptometer at $875 \mathrm{~Hz}, 300 \mathrm{~A} / \mathrm{m}$; hysteresis properties were measured on a Princeton Measurements vibrating sample magnetometer (VSM) 3900-04 at the Magnetic Laboratory at Southern Illinois University, Carbondale. Low-temperature magnetic remanence measurements were performed under zero-field conditions, and as a function of temperature between 10 and $310 \mathrm{~K}$ on sample chips $<1 \mathrm{~g}$ at the Institute for Rock Magnetism, University of Minnesota. The Quantum Design MPMS-5S SQUID (Superconducting Quantum Interference Device) magnetometer measures the magnetic remanence of a sample by moving it through a liquid-helium-cooled superconducting sensing coil, with a sensitivity to $5 \times 10^{-11} \mathrm{Am}^{2}$. The temperature varied by steps of $1 \mathrm{~K}$, at a rate of $1 \mathrm{~K} /$ minute, with a $10 \mathrm{~s}$ stabilizing period and a zero-field environment. NRMs were demagnetized at the Centre d'Etudes et Recherche en Géologie et Environement (CEREGE) at Aix Marseille University, France using 2G Enterprises 760 three axis DC superconducting rock magnetometer. Each sample was progressively demagnetized using an alternating field (AF) up to $170 \mathrm{mT}$.

Secondary Electron Microscopy - Polished petrographic thin-sections were examined at the University of Minnesota's Characterization Facility using a thermally-assisted field emission gun JEOL 6500 scanning electron microscope outfitted with a Centaurus detector for backscattered imaging. Prior to imaging, each specimen was coated with a $50 \AA$ thick layer of amorphous carbon to prevent charging. Specimens were examined using an accelerating voltage of $15 \mathrm{kV}$ and a working distance of $10 \mu \mathrm{m}$. Spot energy dispersive spectroscopy measurements and 
elemental line traverses were collected using a Thermo-Noran Vantage System. The diameter of the interaction volume for elemental measurements was $2.5 \mu \mathrm{m}$ in silicate minerals and $2.0 \mu \mathrm{m}$ in oxide minerals. Matrix correction coefficients ( $\mathrm{Z}, \mathrm{A}$, and $\mathrm{F}$ ) were calculated using the Phi(Rho*z) method. X-ray spectra were collected using counting times of 60 seconds and a probe current of $100 \mathrm{nA}$.

\section{Magnetic results}

\subsection{Magnetic properties measurement system (MPMS)}

We use the magnetization of mantle xenoliths at low-temperature (LT), under zero field conditions, to identify the phases contributing to samples' magnetic remanence. Figure 4 shows the LT temperature ranges of common LT magnetic transitions: Besnus transition of pyrrhotite at ₹30-35 K (e.g., Besnus and Meyer, 1964); Verwey transition of magnetite at $\approx 100-125$ K (e.g., Verwey, 1939; Walz, 2002); Morin transition of hematite at $\approx 250-270 \mathrm{~K}$ (e.g., Morin, 1950; Ozdemir and Dunlop, 2008).

In general, the contribution of pyrrhotite to NRM of mantle xenoliths, even in the case of high sulfide content specimens (Alard et al., 2011), is modest compared to that of magnetite (Friedman, 2011, unpublished; Ferré et al., 2013). Figure 4 documents the variations of magnetization as a function of temperature (first derivative) for representative specimens of the four xenolith suites, at temperatures ranging from 300 to $10 \mathrm{~K}$. Hematite, typically identified through its Morin transition around $265 \mathrm{~K}$, is absent in all samples at the detection limit of the MPMS instrument. Low-Ti magnetite, generally characterized by its Verwey transition around $118 \mathrm{~K}$, occurs distinctively in the Bearpaw Mountains (BPM09B) and the San Carlos (SC05B) specimens, and does not seem present in the Knippa (KN02B) and Kilbourne Hole (KH10) 
specimens, although KH10 may host a small concentration of magnetite. Monoclinic pyrrhotite shows a clear Besnus transition at $32 \mathrm{~K}$ in the Knippa specimen, a subdued transition in the Bearpaw Mountains and Kilbourne Hole specimens, and seems absent from the San Carlos specimen.

\subsection{Hysteresis properties}

The ratio of magnetic remanence $\left(\mathrm{M}_{\mathrm{r}}\right)$ to saturation magnetization normalized to mass $\left(\mathrm{M}_{\mathrm{s}}\right)$ constitutes a proxy for the concentration of ferromagnetic minerals in mantle xenoliths. The ratio of the coercivity of remanence $\left(\mathrm{H}_{\mathrm{cr}}\right)$ to the bulk coercivity $\left(\mathrm{H}_{\mathrm{c}}\right)$ is approximately related to the average grain size of a specimen's ferromagnetic minerals. These two hysteresis ratios, represented in a Day et al. (1977) plot modified after Dunlop (2002), are shown in Figure 5. The Day et al., (1977) plot was originally designed to describe the domain states of magnetite, and not other ferromagnetic phases such as pyrrhotite that may be present in the mantle. Mixtures of single domain (SD) and multi-domain (MD) magnetite grains would plot along the SD-MD line depending on the proportion of SD and MD component, which may lead to the erroneous interpretation that pseudo-single domain (PSD) grains are present (Carter-Stiglitz et al., 2001). Mixtures of superparamagnetic (SP) and SD magnetite grains plot along arrays such as the SP 10 nm-SD line shown on Figure 5 (Dunlop, 2002). Mixtures between different mineral phases, such as magnetite and pyrrhotite, would plot across Dunlop SP-SD mixing lines (Tauxe et al., 1996).

The magnetic hysteresis properties of 25 xenoliths are reported in Figure 5. The Kilbourne Hole and Knippa xenoliths plot statistically in the same field, near the SD end member and display a relatively narrow range of hysteresis ratios. In contrast, the Bearpaw Mountains and San Carlos xenoliths plot near the PSD domain, separately from xenoliths of the previous two localities. The Bearpaw Mountains and San Carlos xenoliths display a longer (along the vertical 
axis) and broader (along the horizontal axis) range of hysteresis ratios than the other xenoliths. These properties indicate that the Bearpaw Mountains and San Carlos xenoliths host mixtures of different ferromagnetic minerals as well as minerals of different grain sizes.

\subsection{Zijderveld plots}

Stepwise demagnetization of the natural remanent magnetization (NRM) was performed using alternating fields, up to $120 \mathrm{mT}$ (Figure 6). Non-altered xenolith specimens showed a single component of NRM and were kept for further tests. The consistent AF demagnetization behavior of most specimens strongly supports that pyrrhotite, a mineral known to demagnetize poorly with the alternating fields method (Rochette et al., 1990), does not contribute significantly to the NRM. The Bearpaw Mountains xenoliths display approximately forty-five times higher $\mathrm{NRM}$ intensities $\left(\mathrm{NRM}=1329 \times 10^{-3} \mathrm{~A} / \mathrm{m}\right)$ than the xenoliths from the other three localities (NRM $\approx 29$ to $43 \times 10^{-3} \mathrm{~A} / \mathrm{m}$ ). The NRM intensities of the San Carlos, Kilbourne Hole and Knippa xenoliths appear remarkably similar. Xenoliths from Knippa fully demagnetized at a field of $45 \mathrm{mT}$ indicating that the NRM is carried by a low-coercivity phase. The xenoliths from Bearpaw Mountains and San Carlos fully demagnetized at fields of $120 \mathrm{mT}$, which indicates that that higher coercivity minerals contribute to the NRM. Finally, the Kilbourne Hole samples were not entirely demagnetized at $120 \mathrm{mT}$, indicating the participation of a very high coercivity mineral in the NRM. 


\subsection{Natural remanent magnetization and low-field susceptibility results}

The low-field magnetic susceptibility of the studied mantle xenoliths generally displays little variation within each locality (Figure 7) with the following means, assuming Gaussian normal distribution: $5060 \pm 150 \times 10^{-6}$ [SI] for Bearpaw Mountains, $600 \pm 10 \times 10^{-6}$ [SI] for San Carlos, $580 \pm 11 \times 10^{-6}[\mathrm{SI}]$ for Kilbourne Hole, $520 \pm 7 \times 10^{-6}[\mathrm{SI}]$ for Knippa. The values for San Carlos, Kilbourne Hole and Knippa xenoliths are very similar to the magnetic susceptibilities reported for mantle xenoliths from other localities (Friedman, 2011; Ferré et al., 2013). The magnetic susceptibilities of the Bearpaw Mountains craton xenoliths vary more substantially than the three off-craton localities and are approximately one order of magnitude larger than previously reported values for fresh mantle xenoliths.

The NRM intensities of our xenoliths follow the same pattern as magnetic susceptibilities where the highest values are recorded by the Bearpaw Mountains specimens. However, in contrast with magnetic susceptibility, the NRM for each set of xenoliths displays large variations over two orders of magnitude, roughly from $10^{-3}$ to $10^{-1} \mathrm{~A} / \mathrm{m}$ (Figure 7). Xenoliths from San Carlos, Kilbourne Hole and Knippa display statistically similar mean values of NRM of $4.38 \pm$ $4.0 \times 10^{-2} \mathrm{~A} / \mathrm{m}$ for San Carlos, $3.02 \pm 3.0 \times 10^{-2} \mathrm{~A} / \mathrm{m}$ for Kilbourne Hole, and $2.93 \pm 1.6 \times 10^{-2}$ A/m for Knippa. In contrast, the Bearpaw Mountains xenoliths show higher NRM values of 1.44 $\pm 1.4 \mathrm{~A} / \mathrm{m}$.

The Koenigsberger ratio $\left(Q_{n}\right)$ is the remanent magnetization (NRM) divided by the induced magnetization caused by the Earth's field: $Q_{n}=\mathrm{NRM} / \chi^{*} \mathrm{H}$, where $\chi$ is the low-field magnetic susceptibility in SI units, and $\mathrm{H}$ is the local geomagnetic field intensity, assumed here to be 40 A/m. Typically, $Q_{n}>1$ indicates that the material's remanent magnetization will be the dominant contribution to magnetic anomalies, while $Q_{n}<1$ indicates that the material's induced 
magnetization will be the dominant origin of magnetic anomalies. The Bearpaw Mountains xenoliths have an average $Q_{n}$ of 12.1, while San Carlos' average $Q_{n}$ is 2.66 , Kilbourne Hole's average $Q_{n}$ is 2.00, and Knippa's average $Q_{n}$ is 2.26 (Figure 7). The Bearpaw Mountain xenoliths display $Q_{n}$ values on average higher than the other three localities, which demonstrates that the magnetic remanence of the upper mantle in this region of Montana would contribute to magnetic anomalies if the geotherm was low enough.

\section{Interpretation and discussion}

Nature of upper mantle magnetic sources - The new rock magnetic and paleomagnetic data from four localities within the interior of the United States show significant variations in the nature and abundance of magnetically remanent phases. The two most common and abundant minerals are magnetite and pyrrhotite (Figure 3). The contribution of other Fe-Cu-Ni sulfides to NRM was not quantified in this study, but it should be small since these phases are volumetrically an order of magnitude less abundant than pyrrhotite. No Fe-Ni alloys, such as josephinite, were identified in the studied xenoliths. Since the Curie temperature of pyrrhotite is $\approx 320^{\circ} \mathrm{C}$ (Dunlop and Özdemir, 2009), this mineral would not carry a magnetic remanence at mantle depths (and temperature), irrespective of the geotherm. The MPMS and magnetic hysteresis results (Figures 4 and 5) demonstrate that the contribution of magnetite to NRM, when present, dominates that of pyrrhotite. Hence, the NRM of magnetite-bearing mantle xenoliths constitutes an adequate proxy for magnetization of the mantle at depth, as long as magnetite was present before ascent and eruption. Recent studies have shown that magnetite can be stable and primary at mantle depth under several circumstances (Smith, 1981, 2010; Friedman, 2011; Ferré et al., 2013). 
On craton, the Bearpaw Mountain xenoliths stand out of the other three localities by their higher NRMs, higher low-field magnetic susceptibilities and higher Koenigsberger ratios (Figure 7). Hence these specimens are the most likely to represent magnetized subcontinental lithospheric mantle. Off craton, the San Carlos, Kilbourne Hole and Knippa xenoliths either do not exhibit conspicuous magnetite inclusions in silicates or host too little magnetite to significantly contribute to the magnetization of the upper mantle.

Pressure dependence of magnetite Curie temperature - The Curie temperature $\left(\mathrm{T}_{\mathrm{C}}\right)$ of pure magnetite increases with increasing pressure but this effect is rarely taken into account in Curie depth calculations (e.g., Ravat et al., 2011): $\mathrm{T}_{\mathrm{C}}=575+2.05 \mathrm{P}$; where $\mathrm{P}=$ pressure in kbar and $\mathrm{T}$ $=$ temperature in ${ }^{\circ} \mathrm{C}$ (e.g., Samara and Giardini, 1969; Schult, 1970). For example, at a pressure of $15 \mathrm{kbars}$, the pressure corrected $\mathrm{T}_{\mathrm{C}} \approx 606^{\circ} \mathrm{C}$. Assuming a low geothermal gradient of $15^{\circ} \mathrm{C} / \mathrm{km}$, this would correspond to an additional layer of $1.75 \mathrm{~km}$ of potentially magnetized rocks. The magnetic susceptibility of magnetite decreases with increasing confining pressure, but only below 0.2 GPa (Kapička, 1992). The saturation remanence $\left(\mathrm{M}_{\mathrm{r}}\right)$ tends to increase with increasing pressure (Gilder et al., 2002; Gilder and LeGoff, 2008; Demory et al., 2013). Although the effect of pressure on the magnetic remanence of magnetite may seem small, it is non-negligible in the upper mantle and its effect should be discernible in the upcoming data expected from the SWARM mission (Olsen et al., 2006; Friis-Christensen et al., 2009). This pressure effect has been integrated in our forward model.

Geotherms - The geothermal gradient at the time of the volcanic eruption that brought the mantle xenoliths to the surface can be determined using the pressure and temperature of equilibration of a suite of mantle xenoliths (e.g., Goncharov et al., 2012). However, this figure does not inform us on the current geotherm present in the region of origin of the xenoliths (e.g., 
Kobussen et al., 2008). An alternative approach to determine heat flow consists in using the depth of the Curie isotherm (e.g., Manea and Manea, 2011; Manea et al., 2012). Therefore, one needs to use heat flow measurements such as those recently compiled for the United States interior by the Geothermal Laboratory at Southern Methodist University (Blackwell et al., 2011). Figure 1 shows inferred temperature at $9.5 \mathrm{~km}$ deduced from a large number of heat-flow measurements. This figure documents significant variations in heat flow across the United States, in which tectonically-active regions of the Western United States are characterized by elevated heat flow. Conversely, certain cratonic domains of the Great Plains and Archean provinces (e.g., Colorado, Wyoming, Montana and the Superior Province) exhibit relatively low heat flows. The extrapolation of crustal temperatures at depths beyond $9.5 \mathrm{~km}$ remains speculative but is nonetheless useful to place thermal constraints on our model. We assume a linear increase of temperature with depth in the continental crust and note that this is a conservative estimate considering the lead paradox in the lower crust (e.g., Hoffman, 1988). It should be noted that most samples of Wasilewski and co-workers came from the Southwest United States where the heat flow is rather high (proximal to a continental rift).

Crustal thicknesses - The thickness of the continental crust determines if the subcontinental lithospheric mantle is shallow enough and cold enough to carry a remanent magnetization. Figure 1 shows that the United States interior comprises several provinces located along cratonic domains where the mantle is both relatively shallow and cold (e.g., northern Minnesota, Wyoming, northern Montana). Such domains present striking geodynamic similarities with stable regions such as the Amsaga belt in the West Africa craton or the Bangui region in the Central Africa craton, where magnetization may extend into the lithospheric mantle (Kochemasov and Chuprov, 1990; Hemant and Maus, 2005b). These domains may constitute 
suitable targets to test if the uppermost mantle contributes to magnetic anomalies using magnetic satellite data.

Metasomatism of the subcontinental lithospheric mantle by the Farallon plate - The flat subduction of the Farallon plate underneath the Western United States has repeatedly been cited as a potential source of metasomatic fluids responsible for Eocene magmatic activity in Montana and Wyoming (e.g., Smith and Griffin, 2005; Facer et al., 2009). This dehydration hypothesis has also been linked to the Laramide orogeny (Humphreys et al., 2003). The Bearpaw Mountain xenoliths present petrographic characteristics strongly supporting in-situ serpentinization of the mantle underlying parts of Montana (Facer et al., 2009). Yet this serpentinization does not seem directly related to the formation of magnetite at high temperature.

Forward model of magnetization in the continental upper mantle - Figure 8 represents the potential contribution of the uppermost mantle underneath the Bearpaw Mountain region of Montana in the case of three low geothermal gradients respectively of $10,12.5$ and $15^{\circ} \mathrm{C} / \mathrm{km}$. This model assumes a uniform mantle geotherm of $3^{\circ} \mathrm{C} / \mathrm{km}$ similar to that documented in other stable regions of the United States (e.g., Raye et al., 2009). Our model shows that with a 45 kmthick continental crust, the thickness of the magnetized mantle layer varies from $45 \mathrm{~km}$ for a geotherm of $10^{\circ} \mathrm{C}$ to zero for a geotherm of $15^{\circ} \mathrm{C}$. This model demonstrates the strong dependency of uppermost mantle magnetization on the geotherm. Conversely, the presence of mantle depth inferred from satellite magnetic data would inform us on the continental geotherm.

Mantle contributions to magnetic anomalies in the United States interior - Mantle xenoliths used in previous investigations pertaining to the United States overrepresented localities of the Rio Grande rift region (Wasilewski et al., 1979; Wasilewski and Mayhew, 1992). The high heat flow of this rift region (Blackwell et al., 2011) precludes any contribution of the uppermost 
mantle to magnetic anomalies. In addition, the specimens of previous studies included altered xenoliths, hence their induced and remanent magnetizations misrepresent the parameters for magnetization at mantle depth. Further, areas characterized by a relatively cold upper mantle combined with a shallow crust-mantle boundary include not only northern Montana but also western South Dakota, northern Michigan, northwestern Texas, eastern Kentucky and eastern Tennessee (Figure 1; Mareschal and Jaupart, 2013). The data from the Bearpaw Mountains emphasize the metasomatic role of fluids related to the Farallon Plate dehydration and the fact that upper mantle contributions to magnetic anomalies might be more common in the United States than previously thought.

\section{Conclusions}

The concept of a uniformly non-magnetic mantle was based on a series of contaminated and altered xenoliths that originated from relatively high heat flow regions such as the Rio Grande Rift or the McMurdo Sound Rift in Antarctica. New collections of fresh xenoliths have provided opportunities to revisit this hypothesis. Our results show, that in four localities from the United States interior, the dominant magnetically remanent phases are magnetite and pyrrhotite. Since pyrrhotite has a low Curie temperature its contribution to magnetic anomalies must be negligible. In contrast, specimens from the cratonic northern part of Montana display high magnetizations coupled with a low geotherm. This type of metasomatised subcontinental lithospheric mantle is likely to contribute to long wavelength magnetic anomalies. 


\section{Acknowledgements}

We acknowledge the assistance of the Vulcan staff at Knippa, Texas in locating xenoliths in the quarry. Our thanks also go to Urmidola Raye who provided two xenolith samples from Knippa. Discussions with Carter Hearn, Douglas Smith, Steve Haggerty, Clive Neal, and Justin Filiberto greatly improved our understanding of mantle petrologic processes. This research was partially supported by NSF-EAR 1345105 to E.C.F and NSF-EAR 1345071 to J.M.F.

\section{References}

Alard, O., Lorand, J.P., Reisberg, L., Bodinier, J.L., Dautria, J.M., and O’Reilly, S., 2011. Volatile-rich metasomatism in Montferrier xenoliths (Southern France): Implications for the abundances of chalcophile and highly siderophile elements in the subcontinental mantle. Journal of Petrology, 52(10): 2009-2045.

Besnus M.J. and Meyer A.J., 1964. Nouvelles données expérimentales sur le magnétisme de la pyrrhotine naturelle. Proc. Int. Conf. Mag., Nottingham, 507-511 (20).

Blackwell, D., Negraru, P.T., and Richards, M.C., 2011. Temperature at depth maps for the conterminous US and geothermal resource estimates. Geothermal Resources Council Transactions, 35 .

Bussod, G.Y.A. and Williams, D.R., 1991. Thermal and kinematic model of the southern Rio Grande rift: inferences from crustal and mantle xenoliths from Kilbourne Hole, New Mexico. Tectonophysics, 197(2-4): 373-389.

Callahan, C.N., 2009. Magnetic Properties of Unaltered and Metasomatized Mantle Xenoliths from the Rio Puerco Volcanic Necks, NM, University of New Mexico, Albuquerque, NM. Carter-Stiglitz, B., Moskowitz, B. and Jackson, M., 2001. Unmixing magnetic assemblages and 
the magnetic behavior of bimodal mixtures. Journal of Geophysical Research: Solid Earth, 106(B11): 26397-26411.

Day, R., Fuller, M. and Schmidt, V.A., 1977. Hysteresis properties of titanomagnetites: grainsize and compositional dependence. Physics of the Earth and Planetary Interiors, 13: 260267.

Demory, F., Rochette, P., Gattacceca, J., and Bezaeva, N.S., 2013. Remanent magnetization and coercivity of rocks under hydrostatic pressure up to $1.4 \mathrm{GPa}$. Geophysical Research Letters, 40: 3858-3862, doi:10.1002/grl.50763.

Dromgoole, E.L. and Pasteris, J.D., 1987. Interpretation of the sulfide assemblages in a suite of xenoliths from Kilbourne Hole, New Mexico. Geological Society of America Special Papers, 215: $25-46$.

Dunlop, D.J., 2002. Theory and application of the Day plot $\left(\mathrm{M}_{\mathrm{rs}} / \mathrm{M}_{\mathrm{s}}\right.$ versus $\left.\mathrm{H}_{\mathrm{cr}} / \mathrm{H}_{\mathrm{c}}\right) .1$. Theoretical curves and tests using titanomagnetite data. Journal of Geophysical Research: Solid Earth, 107(B3): 2056, doi:10.1029/2001JB000486.

Dunlop, D.J. and Ozdemir, O., 2009. Magnetizations in Rocks and Minerals. In: M. Kono (Editor), Geomagnetism. Elsevier, Amsterdam, pp. 277-336.

Facer, J., Downes, H. and Beard, A., 2009. In situ Serpentinization and Hydrous Fluid Metasomatism in Spinel Dunite Xenoliths from the Bearpaw Mountains, Montana, USA. Journal of Petrology, 50(8): 1443-1475.

Ferré, E.C., Friedman, S.A., Martín-Hernández, F.A., Feinberg, J.M., Conder, J.A., and Ionov, D.A., 2013. The magnetism of mantle xenoliths and potential implications for sub-Moho magnetic sources. Geophysical Research Letters, 40(1-6): doi:10.1029/2012GL054100.

Frey, F.A. and Prinz, M., 1978. Ultramafic inclusions from San Carlos, Arizona: Petrologic and 
geochemical data bearing on their petrogenesis. Earth and Planetary Science Letters, 38(1): $129-176$.

Friedman, S.A., 2011. Magnetic properties of mantle xenoliths and implications for long wavelength anomalies, Southern Illinois University, Carbondale, unpublished MSc thesis, 91 p.

Friis-Christensen, E., Lühr, H., Hulot, G., Haagmans, R. and Purucker, M., 2009. Geomagnetic research from space. Eos, 90(25): 213-214.

Gilder, S.A. and Le Goff, M., 2008. Systematic pressure enhancement of titanomagnetite magnetization. Geophysical Research Letters, 35.

Gilder, S.A., LeGoff, M., Peyronneau, J. and Chervin, J.C., 2002. Novel high pressure magnetic measurements with application to magnetite. Geophysical Research Letters, 29(10)(1392): doi:10.1029/2001GL014227.

Goncharov, A.G., Ionov, D.A. and Doucet, L.S., 2012. Thermal state, oxygen fugacity and C-O$\mathrm{H}$ fluid speciation in cratonic lithospheric mantle. new data on peridotite xenoliths from the Udachnaya kimberlite, Siberia. Earth and Planetary Science Letters, doi: 10.1016/j.eps1.2012.09.016.

Hemant, K. and Maus, S., 2005a. Why no anomaly is visible over most of the continent-ocean boundary in the global crustal magnetic field. Physics of The Earth and Planetary Interiors, 149(3-4): 321-333.

Hemant, K. and Maus, S., 2005b. Geological modeling of the new CHAMP magnetic anomaly maps using a geographical information system technique. Journal of Geophysical Research: Solid Earth, 110.

Hofmann, A.W., 1988. Chemical differentiation of the Earth: the relationship between mantle, 
continental crust, and oceanic crust. Earth and Planetary Science Letters, 90(3): 297-314.

Humphreys, E., Hessler, E., Dueker, K., Lang Farmer, G., Erslev, E., and Atwater, T., 2003.

How Laramide-Age Hydration of North American Lithosphere by the Farallon Slab

Controlled Subsequent Activity in the Western United States. International Geology Review, 45(7): 575-595.

Irving, A.J., 1980. Petrology and geochemistry of composite ultramafic xenoliths in alkalic basalts and implications for magmatic processes within the mantle. American Journal of Science, 280-A: 389-426.

Kapicka, A., 1992. Magnetic susceptibility under hydrostatic pressure of synthetic magnetite samples. Physics of The Earth and Planetary Interiors, 70(3-4): 248-252.

Kobussen, A.F., Griffin, W.L., O'Reilly, S.Y. and Shee, S.R., 2008. Ghosts of lithospheres past: Imaging an evolving lithospheric mantle in southern Africa. Geology, 36(7): 515-518.

Kochemasov, G.G. and Chuprov, A.I., 1990. The Bangui magnetic anomaly in Central Africa in the light of new geological evidence. International Geology Review, 32(2): 151-161.

Korhonen, J. V., Fairhead, J. D., Hamoudi, M., Hemant, K., Lesur, V., Mandea, M., Maus, S., Purucker, M., Ravat, D., Sazonova, T., and Thebault, E., 2007, World Digital Magnetic Anomaly Map - CCGM-CGMW/UNESCO, scale 1:50 000000.

Manea, M. and Manea, V., 2011. Curie Point Depth Estimates and Correlation with Subduction in Mexico. Pure and Applied Geophysics, 168: 1489-1499.

Manea, V.C., Perez-Gussinye, M. and Manea, M., 2012. Chilean flat slab subduction controlled by overriding plate thickness and trench rollback. Geology, 40(1): 35-38.

Mareschal, J.C., and Jaupart, C., 2013. Radiogenic heat production, thermal regime and evolution of continental crust. Tectonophysics, 609:524-534. 
Morin, F.J., 1950. Magnetic susceptibility of $\alpha$-Fe2O3 and $\alpha$-Fe2O3 with added titanium. Physics Reviews, 78: 819-820.

Nixon, P.H., 1987. Mantle xenoliths. John Wiley \& Sons, Chichester, 844 pp.

Olsen, N., Haagmans, R., Sabaka, T.J., Kuvshinov, A., Maus, S., Purucker, M.E., Rother, M., Lesur, V., and Mandea, M., 2006. The Swarm End-to-End mission simulator study: A demonstration of separating the various contributions to Earth's magnetic field using synthetic data. Earth, Planets and Space, 58: 359-370.

Ozdemir, O., Dunlop, D., 2008. Morin transition in hematite: Size dependence and thermal hysteresis. Geochemistry, Geophysics, Geosystems, 9(10), Q10Z01.

Purucker, M. and Clark, D., 2011. Mapping and Interpretation of the Lithospheric Magnetic Field, Geomagnetic Observations and Models. IAGA Special Sopron Book Series. Springer Netherlands, pp. 311-337.

Ravat, D., Salem, A., Abdelaziz, A.M.S., Elawadi, E. and Morgan, P., 2011. Probing magnetic bottom and crustal temperature variations along the Red Sea margin of Egypt. Tectonophysics, 510(3,4): 337-344.

Raye, U., Anthony, E.Y., Stern, R.J., Kimura, J.I., Ren, M., Qing, C., and Tani, K., 2011. Composition of the mantle lithosphere beneath south-central Laurentia: Evidence from peridotite xenoliths, Knippa, Texas. Geosphere, 7(3): 710-723.

Rochette, P., Fillion, G., Mattei, J.L., and Deckkers, M.J., 1990. Magnetic transition at 30-34 Kelvin in pyrrhotite: insight into a widespread occurrence of this mineral in rocks. Earth and Planetary Science Letters, 98(3-4): 319-328.

Samara, G.A. and Giardini, A.A., 1969. Effect of pressure on the Néel temperature of magnetite. Physical Review, 186(2): 577-580. 
Schult, A., 1970. Effect of pressure on the Curie temperature of titanomagnetites $\left[(1-\mathrm{x}) \cdot \mathrm{Fe}_{3} \mathrm{O}_{4}\right.$ x. $\left.\mathrm{TiFe}_{2} \mathrm{O}_{4}\right]$. Earth and Planetary Science Letters, 10(1): 81-86.

Smith, D., 1981. Geothermometry and kinetics in a two-spinel peridotite nodule, Colorado Plateau. American Mineralogist, 66: 334-345.

Smith, D., 2010. Antigorite Peridotite, Metaserpentinite, and other Inclusions within Diatremes on the Colorado Plateau, SW USA: Implications for the Mantle Wedge during Low-angle Subduction. Journal of Petrology, 51(6): 1355-1379.

Smith, D. and Griffin, W.L., 2005. Garnetite Xenoliths and Mantle-Water Interactions Below the Colorado Plateau, Southwestern United States. Journal of Petrology, 46(9): 1901-1924.

Tauxe, L., Mullender, T.A.T. and Pick, T., 1996. Potbellies, wasp-waists and superparamagnetsim in magnetic hysteresis. Journal of Geophysical Research, 101: 571-583.

Thebault, E., Purucker, M., Whaler, K.A., Langlais, B. and Sabaka, T.J., 2010. The Magnetic Field of the Earth's lithosphere. Space Science Reviews, 155: 95-127.

Verwey, E.J., 1939. Electronic conduction of magnetite (Fe3O4) and its transition point at low temperature. Nature, 144: 327-328.

Walz, F., 2002. The Verwey transition - a topical review. Journal of Physics: Condensed Matter, 14(12): 285-340.

Warner, R.D. and Wasilewski, P.J., 1995. Magnetic petrology of lower crust and upper mantle xenoliths from McMurdo Sound, Antarctica. Tectonophysics, 249(1-2): 69-92.

Wasilewski, P.J., 1987. Magnetic properties of mantle xenoliths and the magnetic character of the crust-mantle boundary. In: P.H. Nixon (Editor), Mantle Xenoliths. John Wiley and Sons Ltd., London, pp. pp. 577-588.

Wasilewski, P.J. and Mayhew, M.A., 1992. The Moho as a magnetic boundary revisited. 
Geophysical Research Letters, 19(22): 2259-2262.

Wasilewski, P.J., Thomas, H.H. and Mayhew, M.A., 1979. The Moho as a magnetic boundary. Geophysical Research Letters, 6: 541-544.

Young, H.P. and Lee, C.T.A., 2009. Fluid-metasomatized mantle beneath the Ouachita belt of southern Laurentia: Fate of lithospheric mantle in a continental orogenic belt. Lithosphere, 1(6): 370-383.

\section{Figure captions}

Figure 1. Locality map of the four studied localities. Bearpaw Mountains, MT is a blue diamond, San Carlos, AZ (red square), Kilbourne Hole, NM (black circle) and Knippa, TX (green triangle). Other known mantle xenoliths localities are presented as small white circles (Nixon, 1985). Black lines represent depth to the Moho. Temperatures at $9.5 \mathrm{~km}$ depth were calculated by Blackwell et al. (2011).

Figure 2. Optical photomicrographs of representative samples from each locality. A) Bearpaw Mountains, MT, BPM17, shows the phlogopite-spinel dunite xenoliths, phlogophite (Phl), rounded olivine (Ol), orthopyroxene I and II (Opx-I and Opx-II) B) San Carlos, AZ, SC06, a Crrich diopside dunite C) Kilbourne Hole, NM, KH16, a Cr-diopside spinel lherzolite with primary Opx and Ol and D) Knippa, TX, KN09, a spinel lherzolite.

Figure 3. Backscattered electron microprobe images of thin sections from A) Bearpaw Mountains, MT, BPM 17, magnetite (Mag) forms between two Diopside (Di) grains and B) KH10, samples from this locality are rich in sulfides, such as the chalcopyrite (Cc) imaged here. 
Figure 4. Zero-field cooled (ZFC), low-temperature magnetic data, presented as the normalized first derivative of magnetization as a function of temperature $(\delta \mathrm{M} / \delta \mathrm{T})$. BPM09B and SC05B specimens show a change at the Verwey transition, indicating the presence of magnetite. KN02B shows a significant transition consistent with the Besnus pyrrhotite transition. No samples show a change at the Morin transition of hematite.

Figure 5. Magnetic hysteresis properties at the four localities, plotted after Day et al. (1977) and modified by Dunlop (2002). Samples from Knippa, TX and Kilbourne Hole, NM are within the same area, close to the SD end member. The Bearpaw Mountains, MT and San Carlos, AZ samples plot within the PSD field, but follow the SD-MD mixing curve, indicating a combination of both SD and MD grains.

Figure 6. Zijderveld diagrams of selected samples from each locality A) BPM18B linear demagnetization pattern and successful demagnetization at $120 \mathrm{mT}$ indicate that the specimen is unaltered, and contains no high coercivity phases, B) SC06B linear demagnetization pattern and successful demagnetization at $120 \mathrm{mT}$ indicate that the specimen is unaltered, and contains no high coercivity phases, C) KH06A does not demagnetize at $120 \mathrm{mT}$ and therefore, contains a high coercivity phase, most likely due to sulfides and, D) KN09B linear demagnetization pattern and successful demagnetization at $120 \mathrm{mT}$ indicate that the specimen is unaltered, and contains no high coercivity phases 
Figure 7. Natural remanent magnetization vs low field magnetic susceptibility. The low-field magnetic susceptibility has a very narrow range of values for the Rio Grande rift locations while the Bearpaw Mountains show a much higher and wider diversity. NRM intensities for the Rio Grande rift samples are also similar to one another, while the Bearpaw Mountains again, have an overall higher and wider distribution of values. The Koenigsberger ratio of the Rio Grande rift show that these localities are often lower then $Q_{n}=1$, and thus, would not likely contribute to LWMA, while the Bearpaw Mountains, consistently plot above $\mathrm{Q}_{\mathrm{n}}=1$ and would be a likely contributor to LWMA. Samples from Ferré et al. (2013) are shown as open symbols for reference.

Figure 8. Forward model of geothermal gradients beneath the Bearpaw Mountains, MT. Three different crustal geothermal gradients are used to model the potential thickness of magnetic mantle contribution to LWMA. A gradient of $10.0^{\circ} \mathrm{C} / \mathrm{km}$ would equate a potential $45 \mathrm{~km}$ of magnetic mantle, $12.5^{\circ} \mathrm{C} / \mathrm{km}$ would produce $10 \mathrm{~km}$ of magnetic mantle, and $15.0^{\circ} \mathrm{C} / \mathrm{km}$ would produce a mantle too hot to contribute to LWMA.

Figure 9. Magnetic anomaly map of Montana (Korhonen et al., 2007) with the $150^{\circ} \mathrm{C}$ and $200^{\circ} \mathrm{C}$ geotherms at $9.5 \mathrm{~km}$ depth superimposed (Blackwell et al., 2011). Regions of relatively low geotherm broadly correspond to positive magnetic anomalies. The Bearpaw Mountain locality is highlighted by a blue diamond and secondary locality of the Homestead kimberlite is a green star. 


\section{Table captions}

Table 1: Magnetic hysteresis properties, low-field susceptibility, NRM and Koenigsberger ratios. 
Table 1: Magnetic hysteresis properties, low-field susceptibility, NRM and Koenigsberger ratios

\begin{tabular}{|c|c|c|c|c|c|c|c|c|}
\hline & $\begin{array}{l}\text { sample } \\
\text { units }\end{array}$ & $\begin{array}{r}\mathbf{M}_{\mathbf{s}} / \mathbf{m a s s} \\
10^{-3} \mathrm{Am}^{2} / \mathrm{kg}^{2} \\
\end{array}$ & $\begin{array}{r}\mathbf{M}_{\mathbf{r}} / \mathbf{m a s s} \\
10^{-6} \mathrm{Am}^{2} / \mathrm{kg} \\
\end{array}$ & $\begin{array}{r}\mathbf{H}_{\mathbf{c}} \\
10^{3} \mathrm{~A} / \mathrm{m} \\
\end{array}$ & $\begin{array}{r}\mathbf{H}_{\text {cr }} \\
10^{3} \mathrm{~A} / \mathrm{m} \\
\end{array}$ & $\begin{array}{r}\mathbf{K}_{\mathbf{l f}} \\
10^{-6}[S I] \\
\end{array}$ & $\begin{array}{r}\text { NRM } \\
10^{-3} \mathrm{~A} / \mathrm{m} \\
\end{array}$ & $\mathbf{Q}_{n}$ \\
\hline \multirow{14}{*}{ 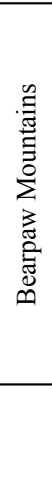 } & BPM03B & 15.12 & 2.39 & 6.58 & 18.85 & 1678 & 233.28 & 3.48 \\
\hline & BPM03C & 15.17 & 1.96 & 5.32 & 21.43 & 1678 & 233.28 & 3.48 \\
\hline & BPM09B & 16.61 & 4.72 & 13.04 & 32.02 & 1023 & 84.16 & 2.06 \\
\hline & BPM10C & 23.24 & 7.21 & 22.31 & 30.99 & 1036 & 348.80 & 8.42 \\
\hline & BPM10D & 29.65 & 8.98 & 22.79 & 31.50 & 1199 & 912.00 & 19.02 \\
\hline & BPM11 & - & - & - & - & 227 & 9.70 & 1.07 \\
\hline & BPM14B & 0.69 & 0.15 & 13.13 & 39.69 & 296 & 26.56 & 2.24 \\
\hline & BPM17C & 288.21 & 63.64 & 18.09 & 32.82 & 8079 & 5408.00 & 16.74 \\
\hline & \begin{tabular}{|l|} 
BPM17D \\
\end{tabular} & 330.96 & 71.21 & 17.01 & 31.09 & 8813 & 2796.80 & 7.93 \\
\hline & BPM18C & 31.42 & 6.05 & 11.86 & 22.04 & 9729 & 2188.80 & 5.62 \\
\hline & BPM18D & 179.89 & 5.11 & 9.66 & 23.64 & 6442 & 2380.80 & 9.24 \\
\hline & average & 93.10 & 17.14 & 13.98 & 28.41 & 3654 & 1329.29 & 7.21 \\
\hline & median & 26.45 & 5.58 & 13.09 & 31.04 & 1678 & 348.80 & 5.62 \\
\hline & stdev & 125.36 & 26.69 & 6.03 & 6.55 & 3762 & 1707.65 & 5.96 \\
\hline \multirow{13}{*}{ 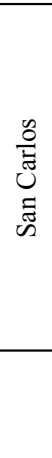 } & SC01A & 0.38 & 0.04 & 6.90 & 20.04 & 532 & 2.05 & 0.10 \\
\hline & \begin{tabular}{|l|} 
SC01B \\
\end{tabular} & 0.09 & 0.01 & 5.28 & 24.29 & 503 & 2.36 & 0.12 \\
\hline & \begin{tabular}{|l|}
$\mathrm{SC} 02$ \\
\end{tabular} & - & - & - & - & 520 & 11.78 & 0.57 \\
\hline & \begin{tabular}{|l|}
$\mathrm{SC} 04$ \\
\end{tabular} & - & - & - & - & 529 & 20.90 & 0.99 \\
\hline & SC04B & 0.39 & 0.03 & 5.50 & 14.71 & 515 & 18.43 & 0.90 \\
\hline & \begin{tabular}{|l|}
$\mathrm{SC} 05$ \\
\end{tabular} & 3.20 & 0.44 & 4.55 & 12.29 & 643 & 102.72 & 3.99 \\
\hline & SC05B & 3.07 & 0.55 & 7.25 & 19.56 & 707 & 114.24 & 4.04 \\
\hline & \begin{tabular}{|l|}
$\mathrm{SC} 06$ \\
\end{tabular} & 2.14 & 0.35 & 6.26 & 16.15 & 773 & 43.52 & 1.41 \\
\hline & \begin{tabular}{|l|}
$\mathrm{SC} 07$ \\
\end{tabular} & - & \begin{tabular}{l|l}
- \\
\end{tabular} & \begin{tabular}{l|l}
- \\
\end{tabular} & - & 531 & 19.26 & 0.91 \\
\hline & \begin{tabular}{|l|} 
SC11 \\
\end{tabular} & - & - & - & - & 706 & 103.04 & 3.65 \\
\hline & average & 1.55 & 0.24 & 5.96 & 17.84 & 595.97 & 43.83 & 1.67 \\
\hline & median & 1.27 & 0.20 & 5.88 & 17.86 & 531.50 & 20.08 & 0.95 \\
\hline & stdev & 1.43 & 0.24 & 1.03 & 4.31 & 101.10 & 44.97 & 1.59 \\
\hline \multirow{13}{*}{$\begin{array}{l}\frac{0}{0} \\
\text { I } \\
0 \\
0 \\
0 \\
0 \\
0\end{array}$} & \begin{tabular}{|l} 
KH02 \\
\end{tabular} & 1.97 & \begin{tabular}{l|l|}
0.84 \\
\end{tabular} & 29.00 & 48.10 & 568 & 51.32 & 2.26 \\
\hline & KH03 & 1.19 & 0.55 & 30.31 & 48.91 & 612 & 40.00 & 1.63 \\
\hline & \begin{tabular}{|l|} 
KH06 \\
\end{tabular} & 1.96 & 0.81 & 29.32 & 47.99 & 598 & 42.56 & 1.78 \\
\hline & \begin{tabular}{|l|} 
KH10 \\
\end{tabular} & 0.35 & 0.09 & 25.68 & 48.10 & 518 & 4.35 & 0.21 \\
\hline & \begin{tabular}{|l|} 
KH11 \\
\end{tabular} & 0.53 & 0.22 & 32.69 & 53.00 & 534 & 8.74 & 0.41 \\
\hline & \begin{tabular}{|l|} 
KH16 \\
\end{tabular} & 0.67 & 0.25 & 29.13 & 52.87 & 627 & 11.49 & 0.46 \\
\hline & $\mathrm{KH} 23$ & - & - & - & - & 579 & 25.92 & 1.12 \\
\hline & \begin{tabular}{|l|} 
KH26 \\
\end{tabular} & - & - & - & - & 570 & 34.88 & 1.53 \\
\hline & KH30 & - & - & - & - & 586 & 39.04 & 1.67 \\
\hline & KH32 & - & - & - & - & 588 & 35.20 & 1.50 \\
\hline & average & 1.11 & 0.46 & 29.36 & 49.83 & 578 & 29.35 & 1.26 \\
\hline & median & 0.93 & 0.40 & 29.23 & 48.51 & 582 & 35.04 & 1.51 \\
\hline & stdev & 0.72 & 0.32 & 2.27 & 2.43 & 33 & 16.02 & 0.68 \\
\hline \multirow{13}{*}{ 营 } & KN02B & 0.75 & 0.28 & 23.43 & 31.59 & 508 & 6.85 & 0.34 \\
\hline & KN09B & 4.38 & 1.41 & 19.83 & 32.50 & 533 & 41.60 & 1.95 \\
\hline & KN15B & 1.36 & 0.38 & 17.36 & 28.68 & 536 & 17.44 & 0.81 \\
\hline & KN16 & - & - & - & - & 486 & 6.30 & 0.32 \\
\hline & KN17 & - & - & - & - & 482 & 2.94 & 0.15 \\
\hline & \begin{tabular}{|l|} 
KN18 \\
\end{tabular} & - & - & - & - & 554 & 98.56 & 4.45 \\
\hline & \begin{tabular}{|l} 
KN199 \\
\end{tabular} & - & - & - & - & 493 & 7.26 & 0.37 \\
\hline & \begin{tabular}{|l|} 
KN23 \\
\end{tabular} & - & - & - & - & 543 & 64.64 & 2.98 \\
\hline & KN37B & 1.24 & 0.37 & 16.53 & 31.60 & 511 & 54.72 & 2.68 \\
\hline & KN123B & 1.66 & 0.77 & 30.49 & 45.33 & 552 & 1.86 & 0.08 \\
\hline & average & 1.88 & 0.64 & 21.53 & 33.94 & 520 & 30.22 & 1.41 \\
\hline & median & 1.36 & 0.38 & 19.83 & 31.60 & 522 & 12.35 & 0.59 \\
\hline & stdev & 1.44 & 0.47 & 5.68 & 6.53 & 27 & 33.24 & 1.52 \\
\hline
\end{tabular}

Note - $M_{s}$ : saturation magnetization; $M_{r}:$ saturation magnetic remanence; $H_{c}:$ magnetic coercivity; $H_{c r}$ : coercivity of magnetic remanence; $K_{l f}$ : low-field magnetic susceptibility; NRM: natural remanent magnetization: $O_{n}$ : Koenigsberger ratio 


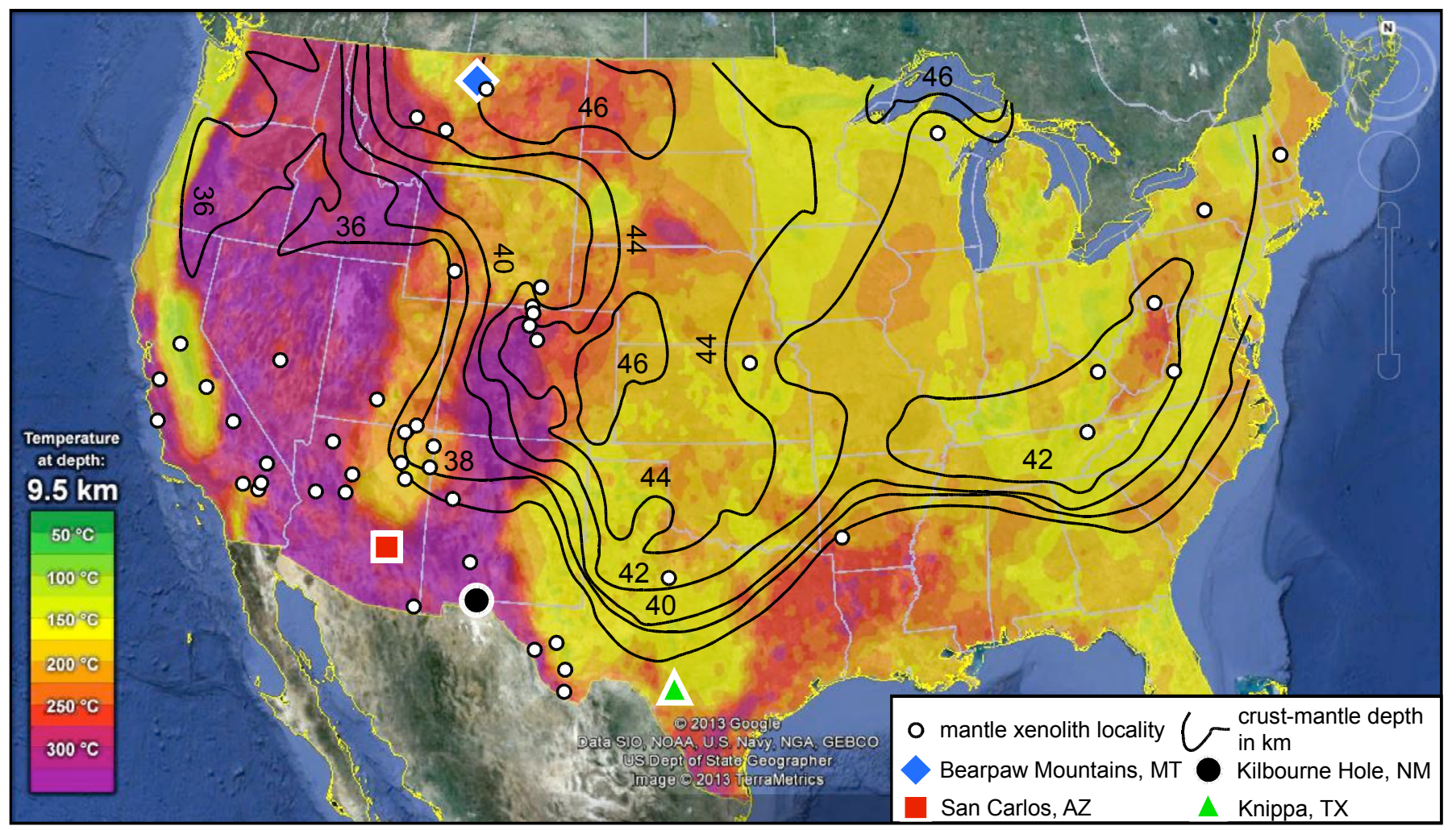



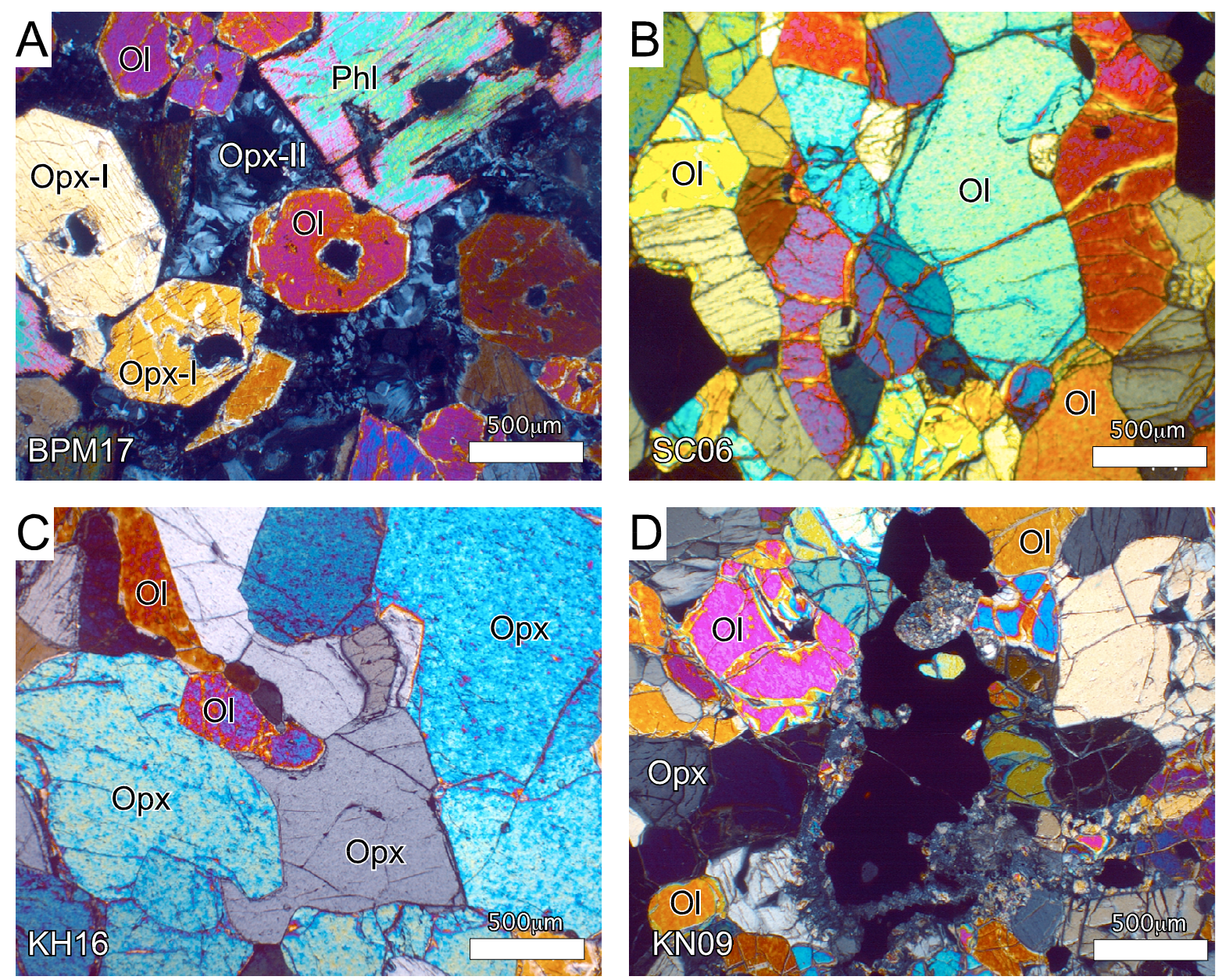

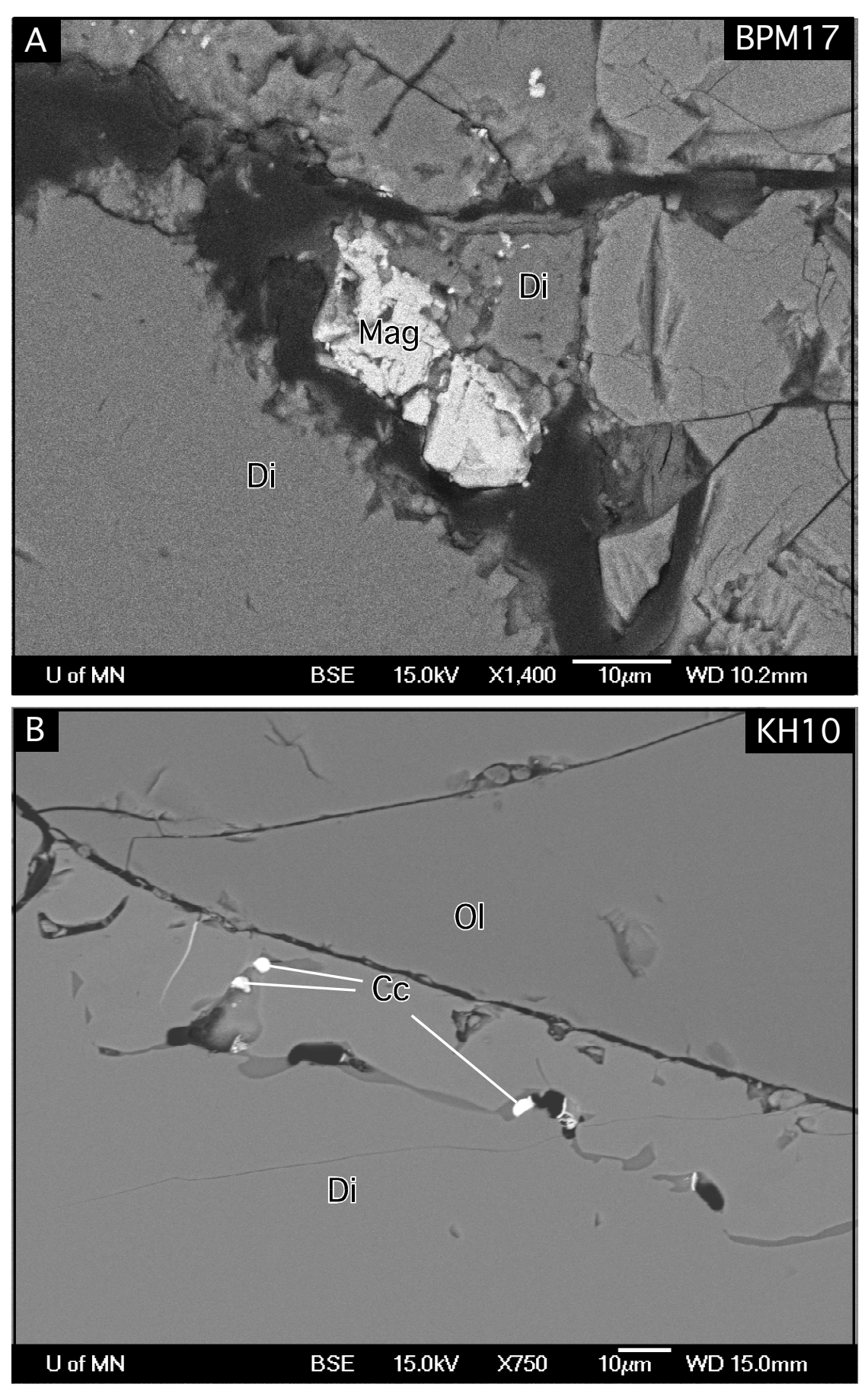


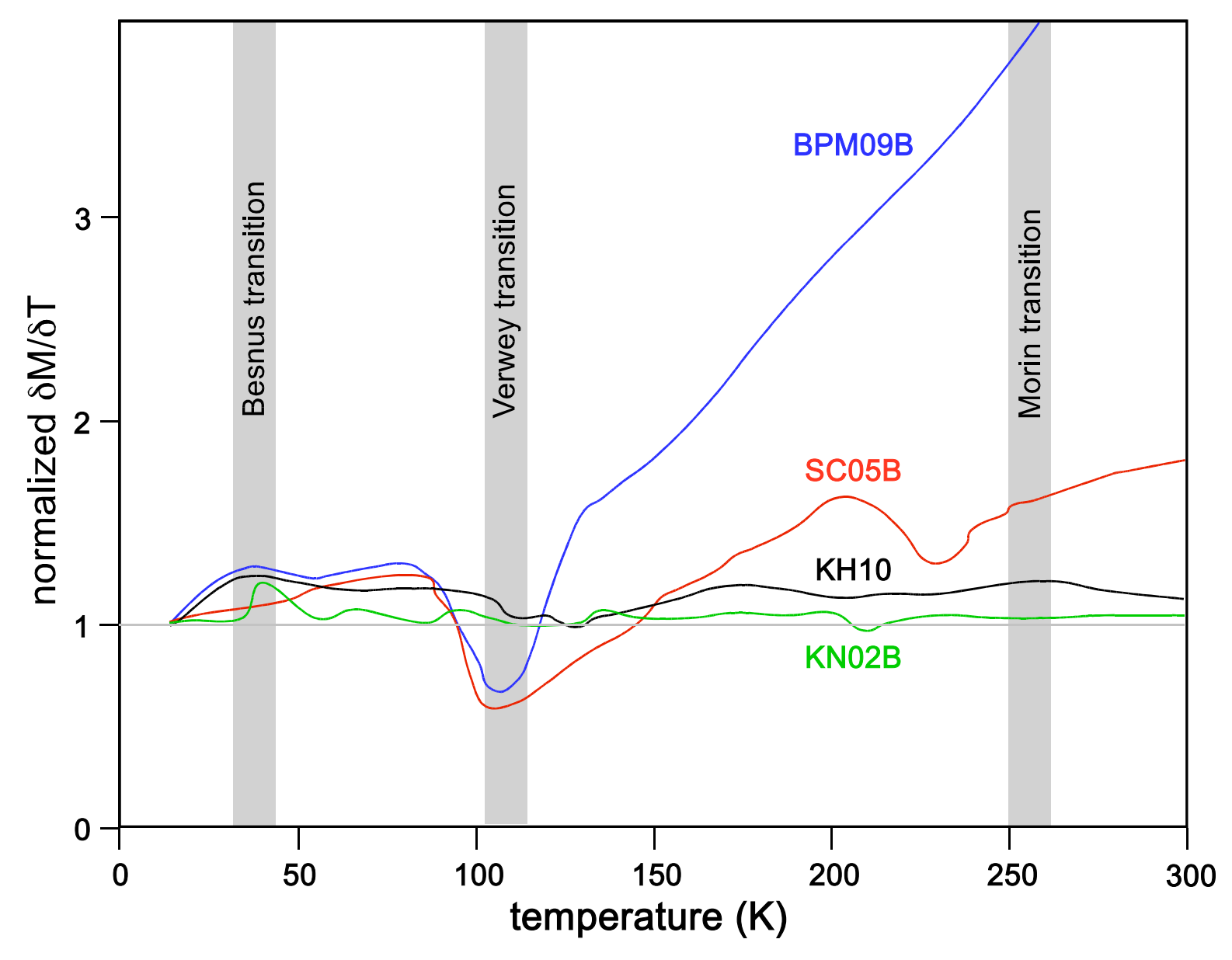




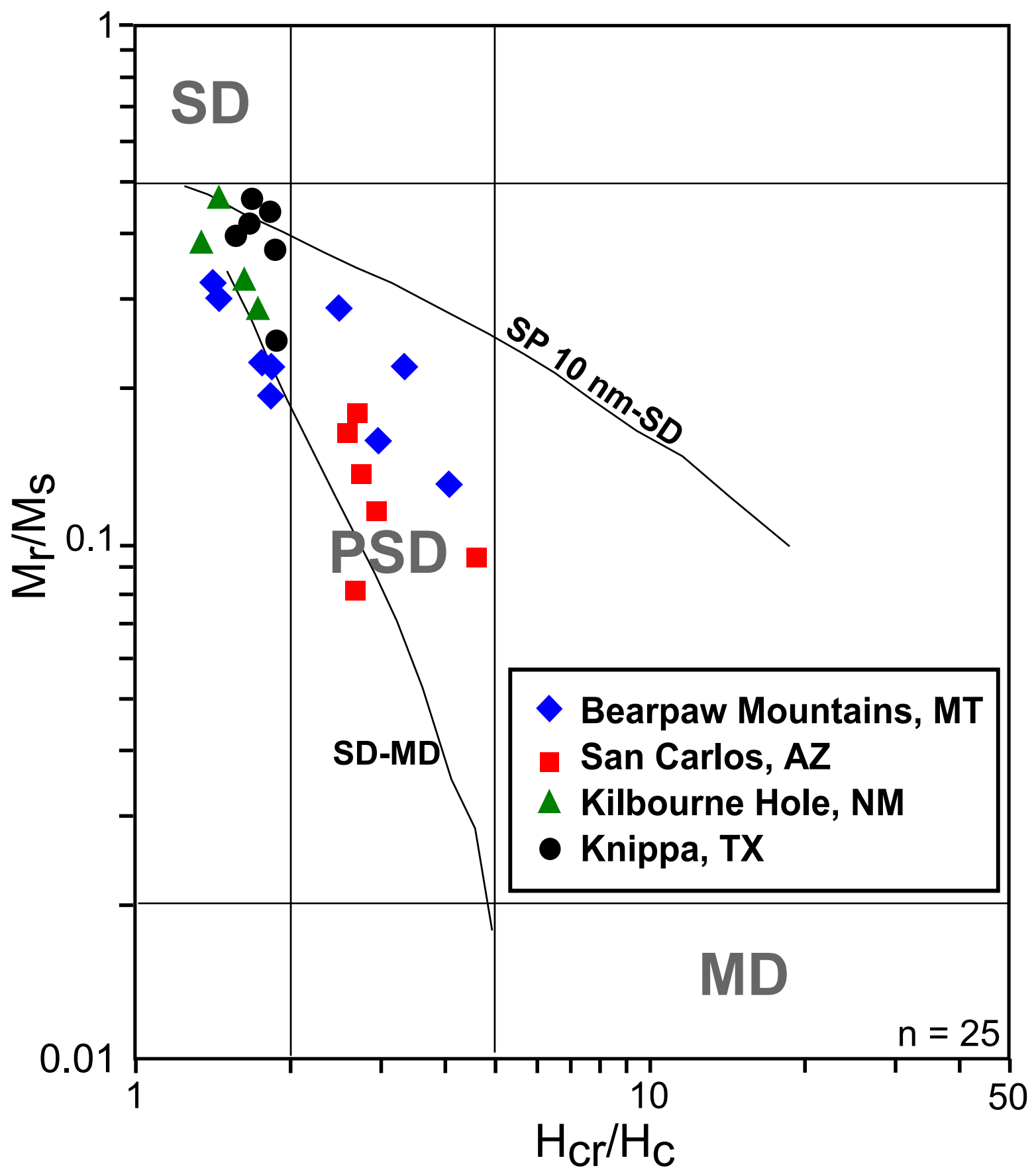




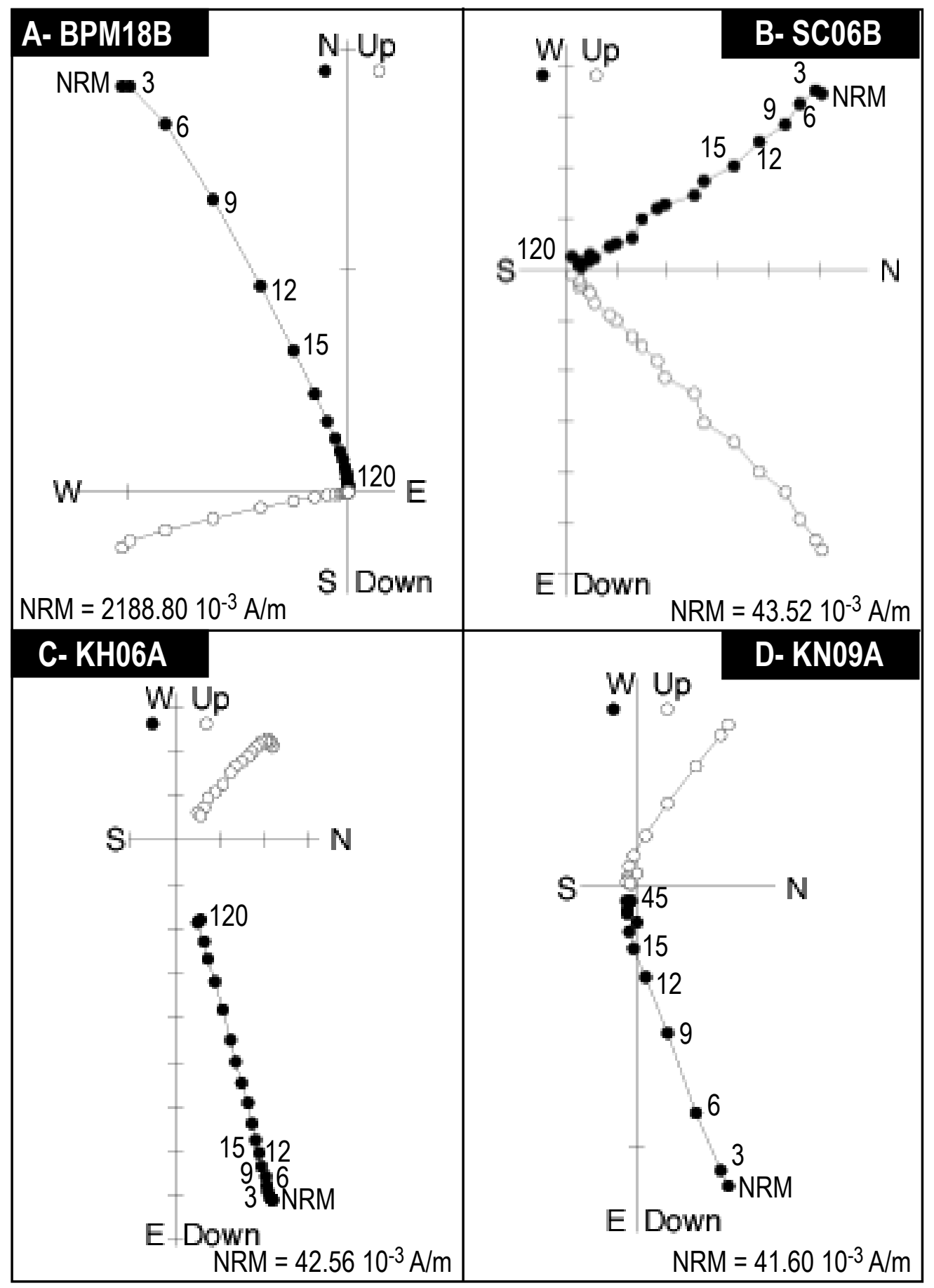

